\title{
Prevalence of Obesity among 6- to 13-Year-Old Kuwaiti Children
}

\author{
Mohamed A.A. Moussa ${ }^{a} \quad$ Azza A. Shaltout ${ }^{b}$ Nashami Al-Sheikh ${ }^{c}$ \\ Nizam Aghac \\ Departments of a Community Medicine and ${ }^{\mathrm{b} P a e d i a t r i c s, ~ F a c u l t y ~ o f ~ M e d i c i n e, ~}$ \\ Kuwait University, ${ }^{c}$ Department of School Health, Ministry of Health, Kuwait
}

\section{Key Words}

Obesity $\cdot$ Children $\cdot$ Kuwait

\begin{abstract}
Objective: To determine the prevalence of obesity among 6- to 13-year-old Kuwaiti children, and to investigate the familial and behavioural factors associated with obesity. Method: A cross-sectional multi-stage stratified random sample of 2,400 schoolchildren $(1,256$ males and 1,144 females) of ages $6-13$ years was selected from the five governorates in Kuwait, between September 1995 and June 1996. Obesity was defined as body mass index (BMI, weight in kilograms per height in metres squared) $>90$ th percentile of the age/sex-specific value of the National Centre of Health Statistics reference population. Data on sociodemographic characteristics, children's behavioural factors, and family history of related diseases in parents were collected by questionnaire. Results: Preva-
\end{abstract}

\begin{tabular}{ll}
\hline KARGER & (1) 1999 S. Karger AG, Basel \\
Fax +4161306 1234 $34-7571 / 99 / 0084-0272 \$ 17.50 / 0$ \\
$\begin{array}{l}\text { E-Mail karger@karger.ch } \\
\text { www.karger.com }\end{array}$ & $\begin{array}{l}\text { Accessible online at: } \\
\text { www.karger.com/journals/mpp }\end{array}$
\end{tabular}

lence of obesity was $26.5 \%$ (95\% confidence interval 24.7-28.3\%). Obesity was more prevalent among the female children from urban areas. BMI was negatively correlated with the number of siblings and child birth order, and positively correlated with blood pressure, after controlling for age and sex. Logistic regression analysis showed significant associations between obesity and family history of obesity (odds ratio $=3.36, p<0.0001$ ), family history of hypertension (odds ratio = 1.37, $p=0.024)$, family history of diabetes (odds ratio $=1.57, p=0.0004$ ) in parents, child birth order (odds ratio $=1.82, \mathrm{p}=$ $0.0002)$, and respiratory diseases in children (odds ratio $=2.08, \mathrm{p}<0.0001$ ). Conclusion: The prevalence rate of obesity in Kuwaiti children is considered to be high. Obesity which is related to family, environment, and individual characteristics needs to be detected and corrected at a young age to prevent its consequences in adulthood.

Copyright $@ 1999$ S. Karger AG, Basel

Dr. Mohamed A.A. Moussa, Department of

Community Medicine and Behavioural Sciences, Faculty of Medicine Kuwait University, PO Box 24923, 13110 Safat (Kuwait)

Tel. +965 5319485, Fax +965 5338948

E-Mail amoussa@hsc.kuniv.edu.kw 


\section{Introduction}

There are no universally accepted criteria for the definition of childhood obesity. Available data from different parts of the world suggest that the prevalence of obesity in children is rising [1]. A study of the prevalence of obesity in New York State has estimated a prevalence of $27.1 \%$ in 6 - to 11 -year-old children [2], while prevalence rates of $15.7 \%$ in boys and $11 \%$ in girls of 4 - to 12 -year-old children were reported from a study in north-east Italy [3]. In New Zealand, obesity rate was 13 and $10 \%$ in male and female children, respectively [4]. A study in Saudi Arabia reported a prevalence of obesity of $15.8 \%$ in 6- to 18 year-old male children [5]. In Kuwait, a study on 6- to 9-year-old children showed that $15.5 \%$ of boys and $16.8 \%$ of girls were overweight [6], while another study revealed that $22 \%$ of children aged $6-17$ years were overweight [7]. The aim of the present study was to determine the prevalence of obesity in 6- to 13-year-old Kuwaiti children and investigate the associated factors.

\section{Subjects and Methods}

\section{Study Population and Sampling Plan}

In order to have a representative profile of Kuwaiti children, a sample was obtained by selecting children with different socioeconomic backgrounds and environmental conditions from the five governorates of Kuwait using the multi-stage stratified random sampling [8]. The sampling frame was obtained from the 1995/96 school districts' registers which included lists of primary and junior schools. One primary and one junior school for each gender were randomly selected from each governorate, i.e. a total of 20 schools. In each school, a number of children proportional to the total number of children in each level (there are four levels in primary and four levels in junior) were selected by simple random sampling using students' lists provided by the school as sampling frame. Children suffering from endocrine or metabolic diseases which may affect their growth were excluded. Five children ( 2 diabetics, 1 with chronic liver disease, and 2 with kidney disease) were excluded, and 3 children were absent on the survey day, and hence 2,400 students (1,256 males and 1,144 females) were available for analysis.

A specially designed questionnaire was used to collect data through structured interview of parents and children. The questionnaire included four sections: (1) sociodemographic characteristics (birth and measurement dates, gender, education and occupation of parents, number of alive siblings, and order of the child in the family); (2) behavioural factors (physical activity, and type of feeding in infancy, breast or bottle); (3) diseases related to obesity in the child (respiratory and bone diseases) and in parents (diabetes, ischaemic heart disease, and hypertension), and (4) clinical data (weight, height, and blood pressure). The study protocol was approved by the Medical Research Ethics Committee of the Faculty of Medicine, Kuwait University. Informed consent was obtained from parents of selected children. The socioeconomic status (SES) score for a child was based on education and occupation of parents. The questionnaire was pre-tested on 10 children from each governorate.

\section{Measurements}

Medical examination of the children took place in each school during the period September 1995 to June 1996. Each child was subjected to the examination by 1 paediatrician and 3 research assistants who were appropriately trained. Weight was measured (to the nearest $0.1 \mathrm{~kg}$ ) using the physician's balance beam scale with attached stadiometer (Health o meter 400/ 402 Series, Ill., USA), and the child was barefooted, wearing light clothes. Height was measured (to the nearest $0.5 \mathrm{~cm}$ ) by the stadiometer with the child's heels, back and occiput touching the vertical bar while bringing the horizontal bar down closely touching the vertex. Body mass index (BMI, weight in kilograms divided by the square of height in metres) was used as an obesity index because it is independent of stature and it has a high correlation with other fatness indicators [9].

Blood pressure was measured by 1 physician using standard mercury sphygmomanometer, Littman classic II stethoscope, and three different sizes of paediatric cuffs to allow for the choice of a suitable size for the children. To relieve nervous tension, the children were seated for about $10 \mathrm{~min}$ before checking their blood pressure. Two readings were recorded on the right arm of the child, and the second reading was used in the study. 
Table 1. Regional distribution of obesity (BMI $>90$ th percentile of the NCHS reference population) in Kuwaiti schoolchildren by governorate, gender and age, 1996

\begin{tabular}{|c|c|c|c|c|c|c|c|c|}
\hline \multirow[t]{2}{*}{ Age, years } & \multicolumn{2}{|l|}{ Capital } & \multicolumn{2}{|l|}{ Hawalli } & \multicolumn{2}{|c|}{ Farwaniya } & \multicolumn{2}{|l|}{ Jahra } \\
\hline & $\begin{array}{l}\text { male } \\
(\mathrm{n}=196)\end{array}$ & $\begin{array}{l}\text { female } \\
(\mathrm{n}=195)\end{array}$ & $\begin{array}{l}\text { male } \\
(\mathrm{n}=261)\end{array}$ & $\begin{array}{l}\text { female } \\
(\mathrm{n}=227)\end{array}$ & $\begin{array}{l}\text { male } \\
(\mathrm{n}=338)\end{array}$ & $\begin{array}{l}\text { female } \\
(\mathrm{n}=261)\end{array}$ & $\begin{array}{l}\text { male } \\
(\mathrm{n}=190)\end{array}$ & $\begin{array}{l}\text { female } \\
(\mathrm{n}=192)\end{array}$ \\
\hline 6 & $5 \quad(2.6)$ & $2(1.0)$ & $6 \quad(2.3)$ & $7 \quad(3.1)$ & $6 \quad(1.8)$ & $6 \quad(2.3)$ & $0 \quad(0.0)$ & $0 \quad(0.0)$ \\
\hline 7 & $3(1.5)$ & $7 \quad(3.6)$ & $10(3.8)$ & $11(4.9)$ & $10 \quad(3.0)$ & $6 \quad(2.3)$ & $2(1.1)$ & $4 \quad(2.1)$ \\
\hline 8 & $7 \quad(3.6)$ & $6 \quad(3.1)$ & $8 \quad(3.1)$ & $7 \quad(3.1)$ & $16(4.7)$ & 11 (4.2) & 3 (1.6) & $3(1.7)$ \\
\hline 9 & 9 (4.6) & $9(4.6)$ & 3 (1.2) & $5(2.2)$ & $12(3.6)$ & $12(4.6)$ & $4 \quad(2.1)$ & $2(1.0)$ \\
\hline 10 & $4(2.0)$ & 9 (4.6) & 9 (3.6) & $13(5.7)$ & $12(3.6)$ & $6(2.3)$ & 3 (1.6) & $2(1.0)$ \\
\hline 11 & $9(4.6)$ & $8 \quad(4.1)$ & $12(4.6)$ & $4 \quad(1.8)$ & $15 \quad(4.4)$ & $7 \quad(2.7)$ & $5 \quad(2.6)$ & $7 \quad(3.7)$ \\
\hline 12 & $10(5.1)$ & $10(5.1)$ & $16(6.1)$ & $12(5.3)$ & $18 \quad(5.3)$ & $17(6.5)$ & $6 \quad(3.2)$ & $9 \quad(4.7)$ \\
\hline 13 & $9(4.6)$ & $7 \quad(3.6)$ & $13(5.0)$ & $13 \quad(5.7)$ & $24 \quad(7.1)$ & $14 \quad(5.4)$ & 15 (7.9) & $12(6.3)$ \\
\hline $\begin{array}{l}\text { Primary } \\
\text { (6-9 years) }\end{array}$ & $24(12.2)$ & $24(12.3)$ & $27(10.3)$ & $30(13.2)$ & $44(13.0)$ & $35(13.4)$ & 9 (4.7) & 9 (4.7) \\
\hline $\begin{array}{l}\text { Junior } \\
\text { (10-13 years) }\end{array}$ & $32(16.3)$ & $34(17.4)$ & $50(19.2)$ & $42(18.5)$ & $69(20.4)$ & $44(16.9)$ & $29(15.3)$ & $30(15.6)$ \\
\hline All ages & $56(28.6)$ & $58(29.7)$ & $77(29.5)$ & $72(31.7)$ & $113(33.4)$ & $79(30.3)$ & $38(20.0)$ & $39(20.3)$ \\
\hline
\end{tabular}

\section{Behavioural Factors}

Behavioural factors included physical activity, and the type of feeding in infancy. Our criteria for classification of physical activity were: light (normal daily routine with light recreational activities at school); moderate (participation in an exercise programme 3 days per week for 20-30 min); heavy (participation in an exercise programme for more than 3 days per week for at least $1 \mathrm{~h}$ per day). A child was defined as obese if his/her BMI value was $>$ the 90th percentile of the age/ sex-specific BMI value of the National Centre for Health Statistics (NCHS) reference population [10], which is widely used for comparison of nutritional status by many populations.

\section{Statistical Methods}

Data were analysed using SPSS [11], and $\mathrm{p} \leq 0.05$ was the cut-off level for significance. The chi-square test was used to assess the association between two categorical variables, and the Student $t$ was used to test the difference between the means of two quantitative variables. Partial correlation was used to assess the association between quantitative variables, after controlling for confounding variables. The Mantel-Haenszel procedure was used to calculate odds ratios and their 95\% confidence intervals (CI) [12]. The multiple logistic regression analysis was used to adjust for con- founding between variables. The dependent variable was binary ( 0 for non-obese and 1 for obese), while independent variables were a mixture of categorical and quantitative variables.

\section{Results}

Table 1 depicts the distribution of obese schoolchildren according to governorate, gender and age. The overall obesity rate was $26.5 \%$ (95\% CI, 24.7-28.3\%). On the governorate level, obesity rates were highest in urban governorates (Farwaniya 32.1\%, Hawalli $30.6 \%$ and the Capital $29.2 \%$ ), and lowest in rural governorates (Jahra $20.2 \%$ and Ahmadi 19.1\%). On gender grounds, obesity rate was $27 \%$ in females versus $26 \%$ in males. The rate of obesity in juniors (10-13 years) was almost double the rate in primary (6-9 years) schoolchildren. On the primary level, obesity was more prevalent in males (20.5\%) than among females (19.6\%). This pattern was reversed in the junior level as the obesity 


\begin{tabular}{|c|c|c|c|}
\hline \multicolumn{2}{|l|}{ Ahmadi } & \multicolumn{2}{|l|}{ Total } \\
\hline $\begin{array}{l}\text { male } \\
(\mathrm{n}=271)\end{array}$ & $\begin{array}{l}\text { female } \\
(\mathrm{n}=269)\end{array}$ & $\begin{array}{l}\text { male } \\
(\mathrm{n}=1,256)\end{array}$ & $\begin{array}{l}\text { female } \\
(\mathrm{n}=1,144)\end{array}$ \\
\hline 3 & $2(0.7)$ & 20 & $17 \quad(1.5)$ \\
\hline $1 \quad(0.4)$ & $6 \quad(2.2)$ & $26 \quad(2.1)$ & $34 \quad(3.0)$ \\
\hline 3 (1.1) & $2(0.7)$ & $37 \quad(3.0)$ & $29(2.5)$ \\
\hline $6 \quad(2.2)$ & 3 (1.1) & $34 \quad(2.7)$ & 31 \\
\hline 5 (1.9) & $12(4.5)$ & $33 \quad(2.6)$ & $42 \quad(3.7)$ \\
\hline 3 (1.1) & 9 (3.4) & $44 \quad(3.5)$ & $35 \quad(3.1)$ \\
\hline 11 & $8 \quad(3.0)$ & 61 & $56 \quad(4.9)$ \\
\hline $10(3.7)$ & 19 & $71 \quad(5.7)$ & $65 \quad(5.7)$ \\
\hline 13 & $13(4.8)$ & $117(9.3)$ & 111 \\
\hline $29(10.7)$ & $48(17.8)$ & $209(16.6)$ & $198(17.3)$ \\
\hline $42(15.5)$ & $61(22.7)$ & $326(26.0)$ & $309(27.0)$ \\
\hline
\end{tabular}

rate was higher in females $(34.1 \%)$ than in males $(30.5 \%)$. Also, obesity rate increased with the increase in age. Demographic profile (table 2) showed that obesity rate was higher in children whose mothers were working, in children of low birth order in the family, and in families with less number of alive siblings.

As an evidence that prevalence of obesity depends upon the cut-off level used, prevalence rates were also calculated using the criteria for obesity 'BMI SD score $>2.0$ ', which is equivalent to $>95$ th percentile. The overall obesity rate was $18.4 \%$ (19.4\% in females, $17.4 \%$ in males). Similarly, urban governorates had higher obesity rates (Farwaniya 22.9\%, Hawalli 21.3\% and the Capital $19.4 \%$ ), as compared to rural governorates (Jahra 13.6\% and Ahmadi 13.3\%).

Table 2. Sociodemographic characteristics of schoolchildren aged 6-13 years, Kuwait, 1996

\begin{tabular}{|c|c|c|c|c|c|}
\hline \multirow[t]{2}{*}{ Variable } & \multicolumn{2}{|c|}{ Obese } & \multicolumn{2}{|c|}{ Non-obese } & \multirow[t]{2}{*}{$\mathrm{p}$ value ${ }^{1}$} \\
\hline & $\mathrm{n}$ & $\%$ & $\mathrm{n}$ & $\%$ & \\
\hline \multicolumn{6}{|l|}{ Sex } \\
\hline Male & 326 & 51.3 & 930 & 52.7 & \multirow[t]{2}{*}{ NS } \\
\hline Female & 309 & 48.7 & 835 & 47.3 & \\
\hline \multicolumn{6}{|c|}{ Mother occupation } \\
\hline Not working & 405 & 64.6 & 1,210 & 69.3 & \multirow{2}{*}{0.034} \\
\hline Working & 222 & 35.4 & 536 & 30.7 & \\
\hline \multicolumn{6}{|l|}{ Social class } \\
\hline Low & 206 & 33.6 & 649 & 38.1 & \multirow[t]{3}{*}{ NS } \\
\hline Medium & 354 & 57.7 & 926 & 54.4 & \\
\hline High & 53 & 8.6 & 128 & 7.5 & \\
\hline \multicolumn{6}{|l|}{ Alive siblings } \\
\hline $0-3$ & 176 & 28.0 & 414 & 23.6 & \multirow[t]{2}{*}{0.028} \\
\hline$>3$ & 453 & 72.0 & 1,343 & 76.4 & \\
\hline \multicolumn{6}{|c|}{ Child's birth order } \\
\hline 1 & 143 & 22.5 & 323 & 18.3 & \multirow{3}{*}{$<0.001$} \\
\hline $2-4$ & 337 & 53.1 & 874 & 49.5 & \\
\hline$>4$ & 155 & 24.4 & 568 & 32.2 & \\
\hline
\end{tabular}

Med Principles Pract 1999;8:272-280

275 
Table 3. BMI of schoolchildren aged 6-13 years by gender and age, Kuwait, 1996

\begin{tabular}{|c|c|c|c|c|c|}
\hline \multirow{2}{*}{$\begin{array}{l}\text { Age } \\
\text { years }\end{array}$} & \multirow[t]{2}{*}{ Variable } & \multicolumn{2}{|l|}{ Obese } & \multicolumn{2}{|l|}{ Non-obese } \\
\hline & & male & female & male & female \\
\hline \multirow[t]{2}{*}{6} & $\mathrm{n}$ & 20 & 17 & 123 & 110 \\
\hline & $\mathrm{BMI}, \mathrm{kg} / \mathrm{m}^{2}$ & $21.6 \pm 3.4$ & $20.5 \pm 2.1^{\mathrm{NS}}$ & $15.6 \pm 3.0$ & $15.1 \pm 1.6^{* *}$ \\
\hline \multirow[t]{2}{*}{7} & $\mathrm{n}$ & 26 & 34 & 113 & 108 \\
\hline & $\mathrm{BMI}, \mathrm{kg} / \mathrm{m}^{2}$ & $21.3 \pm 2.7$ & $20.5 \pm 2.1^{\mathrm{NS}}$ & $15.6 \pm 1.1$ & $15.3 \pm 1.5^{\mathrm{NS}}$ \\
\hline \multirow[t]{2}{*}{8} & $\mathrm{n}$ & 37 & 29 & 101 & 101 \\
\hline & $\mathrm{BMI}, \mathrm{kg} / \mathrm{m}^{2}$ & $21.8 \pm 2.3$ & $23.7 \pm 3.7^{*}$ & $16.2 \pm 1.3$ & $16.2 \pm 1.6^{\mathrm{NS}}$ \\
\hline \multirow[t]{2}{*}{9} & $\mathrm{n}$ & 34 & 31 & 105 & 108 \\
\hline & $\mathrm{BMI}, \mathrm{kg} / \mathrm{m}^{2}$ & $25.0 \pm 3.8$ & $24.7 \pm 3.0^{\mathrm{NS}}$ & $16.6 \pm 1.4$ & $16.5 \pm 2.2^{\mathrm{NS}}$ \\
\hline \multirow[t]{2}{*}{10} & $\mathrm{n}$ & 33 & 42 & 102 & 98 \\
\hline & BMI, $\mathrm{kg} / \mathrm{m}^{2}$ & $25.3 \pm 4.1$ & $25.2 \pm 2.4^{\mathrm{NS}}$ & $17.3 \pm 1.8$ & $17.6 \pm 2.5^{\mathrm{NS}}$ \\
\hline \multirow[t]{2}{*}{11} & $\mathrm{n}$ & 44 & 35 & 103 & 96 \\
\hline & $\mathrm{BMI}, \mathrm{kg} / \mathrm{m}^{2}$ & $26.8 \pm 3.2$ & $27.9 \pm 4.0^{\mathrm{NS}}$ & $17.4 \pm 2.2$ & $18.3 \pm 2.4^{* *}$ \\
\hline \multirow[t]{2}{*}{12} & $\mathrm{n}$ & 61 & 56 & 127 & 110 \\
\hline & $\mathrm{BMI}, \mathrm{kg} / \mathrm{m}^{2}$ & $27.4 \pm 4.4$ & $28.9 \pm 3.6^{* *}$ & $17.9 \pm 2.3$ & $19.5 \pm 2.6^{* * *}$ \\
\hline \multirow[t]{2}{*}{13} & $\mathrm{n}$ & 71 & 65 & 156 & 104 \\
\hline & $\mathrm{BMI}, \mathrm{kg} / \mathrm{m}^{2}$ & $28.7 \pm 4.5$ & $29.4 \pm 3.7^{\mathrm{NS}}$ & $18.7 \pm 2.3$ & $20.3 \pm 2.6^{* * *}$ \\
\hline \multirow[t]{2}{*}{ All ages } & $\mathrm{n}$ & 326 & 309 & 930 & 835 \\
\hline & $\mathrm{BMI}, \mathrm{kg} / \mathrm{m}^{2}$ & $25.7 \pm 4.6$ & $26.2 \pm 4.4^{\mathrm{NS}}$ & $17.0 \pm 2.1$ & $17.3 \pm 2.8^{\mathrm{NS}}$ \\
\hline
\end{tabular}

Values represent the untransformed mean \pm standard deviation. Analysis used natural logarithms of BMI. ${ }^{* * *} \mathrm{p}<0.001,{ }^{* *} \mathrm{p}<0.01 ;{ }^{*} \mathrm{p}<0.05 ; \mathrm{NS}=$ not significant (male vs. female, by unpaired $t$ test).

Partial correlation of BMI with blood pressure after controlling for age and gender showed positive correlation $(\mathrm{r}=0.417$ and 0.365 for systolic and diastolic blood pressure, respectively, $\mathrm{p}<0.01)$. Systolic and diastolic blood pressure levels were higher in obese children, and steadily increased as age increased. Thirty-one (4.9\%) of the obese children had their systolic blood pressure higher than $120 \mathrm{~mm} \mathrm{Hg}$, and diastolic blood pressure higher than $80 \mathrm{~mm} \mathrm{Hg}$ when compared to 7 $(0.4 \%)$ non-obese children. Table 3 shows the change in BMI by gender and age. BMI showed negative correlation with the number of alive siblings $(\mathrm{r}=-0.125, \mathrm{p}<0.05)$ and child birth order $(r=-0.09, p<0.05)$.
Obesity was significantly related to the type of feeding in infancy. The risk for a child on bottle feed to become obese was 1.56 times more than if he was breast-fed (odds ratio $=$ $1.56, \mathrm{p}=0.006$ ). In addition, family history of obesity, diabetes mellitus, and hypertension in parents, and respiratory and bone diseases in children were found to be significant associated factors with obesity (table 4).

Multiple logistic regression model included obesity status ( 0 for non-obese and 1 for obese) as the dependent variable, and 14 independent variables (mother's education, maternal employment, social class, number of siblings, child's birth order, child's smoking habit, physical activity, type of feeding in 
Table 4. Behavioural factors and associated diseases with obesity in schoolchildren aged 6-13 years, Kuwait, 1996

\begin{tabular}{|c|c|c|c|c|c|c|c|}
\hline \multirow[t]{2}{*}{ Variable } & \multicolumn{2}{|c|}{ Obese } & \multicolumn{2}{|c|}{ Non-obese } & \multirow{2}{*}{$\begin{array}{l}\text { Odds ratio } \\
\text { (unadjusted) }\end{array}$} & \multirow[t]{2}{*}{$95 \% \mathrm{CI}$} & \multirow[t]{2}{*}{$\mathrm{p}$ value } \\
\hline & $\mathrm{n}$ & $\%$ & $\mathrm{n}$ & $\%$ & & & \\
\hline \multicolumn{8}{|c|}{ Physical activity } \\
\hline Light & 138 & 21.7 & 369 & 20.9 & 0.83 & $0.68,1.02$ & NS \\
\hline Moderate & 264 & 41.6 & 803 & 45.5 & 0.95 & $0.74,1.22$ & NS \\
\hline Heavy & 233 & 36.7 & 591 & 33.5 & 1.00 & & \\
\hline \multicolumn{8}{|c|}{ Type of feeding } \\
\hline Bottle & 100 & 15.9 & 220 & 12.5 & 1.56 & $1.14,2.13$ & 0.006 \\
\hline Combined & 413 & 65.7 & 1,139 & 64.9 & 1.24 & $0.98,1.57$ & NS \\
\hline Breast & 116 & 18.4 & 397 & 22.6 & 1.00 & & \\
\hline \multicolumn{8}{|c|}{ Family history of obesity } \\
\hline Yes & 227 & 43.6 & 319 & 18.1 & 3.44 & $2.82,4.20$ & $<0.001$ \\
\hline No & 358 & 56.4 & 1,446 & 81.9 & 1.00 & & \\
\hline \multicolumn{8}{|c|}{ Diseases in child } \\
\hline \multicolumn{8}{|c|}{ Bone disease } \\
\hline Yes & 18 & 2.9 & 21 & 1.2 & 2.44 & $1.29,4.61$ & 0.007 \\
\hline No & 632 & 97.1 & 1,736 & 98.8 & 1.00 & & \\
\hline \multicolumn{8}{|c|}{ Respiratory disease } \\
\hline Yes & 101 & 16.1 & 136 & 7.7 & 2.28 & $1.73,3.00$ & $<0.001$ \\
\hline No & 528 & 83.9 & 1,621 & 92.3 & 1.00 & & \\
\hline \multicolumn{8}{|c|}{ Diseases in family } \\
\hline \multicolumn{8}{|c|}{ Diabetes mellitus } \\
\hline Yes & 179 & 28.5 & 319 & 18.2 & 1.80 & $1.45,2.22$ & $<0.001$ \\
\hline No & 449 & 71.5 & 1,438 & 81.8 & 1.00 & & \\
\hline \multicolumn{8}{|c|}{ Ischaemic heart } \\
\hline Yes & 21 & 3.3 & 69 & 3.9 & 0.85 & $0.51,1.39$ & NS \\
\hline No & 608 & 96.7 & 1,688 & 96.1 & 1.00 & & \\
\hline \multicolumn{8}{|c|}{ Hypertension } \\
\hline Yes & 128 & 20.3 & 229 & 13.0 & 1.71 & $1.34,2.16$ & $<0.001$ \\
\hline No & 501 & 79.7 & 1,528 & 87.0 & 1.00 & & \\
\hline
\end{tabular}

Differences in total frequency are due to missing data. $\mathrm{CI}=$ Confidence interval.

1 Mantel-Haenszel procedure. NS = Not statistically significant.

infancy, family history of obesity, bone and respiratory diseases in the child, family history of hypertension, ischaemic heart disease, diabetes mellitus in parents, in addition to the two covariates, age and sex). Family history of obesity, hypertension and diabetes mellitus in parents, child's birth order, and respiratory diseases in the child were the significant factors selected by the logistic regression model (table 5). 
Table 5. Significant factors associated with obesity selected by the stepwise logistic regression, schoolchildren aged 6-13 years, Kuwait, 1996

\begin{tabular}{llllr}
\hline Step & Factor & $\begin{array}{l}\text { Odds ratio } \\
\text { (adjusted) }\end{array}$ & $95 \%$ CI & p value \\
\hline 1 & Family history of obesity & 3.36 & $2.71,4.16$ & $<0.0001$ \\
2 & Respiratory disease in child & 2.08 & $1.53,2.82$ & $<0.0001$ \\
3 & Child's birth order & & & 0.0003 \\
& $>4$ & 1.00 & & 0.0004 \\
& $2-4$ & 1.61 & $1.24,2.09$ & 0.0002 \\
& 1 & 1.82 & $1.33,2.50$ & 0.0004 \\
4 & Family history of diabetes & 1.57 & $1.22,2.09$ & 0.024 \\
5 & Family history of hypertension & 1.37 & $1.04,1.81$ & \\
\hline & & & & \\
& & & & \\
\hline
\end{tabular}

\section{Discussion}

This study focuses on the prevalence of obesity and the quantitative effects of a number of factors that are believed to be associated with the occurrence of obesity. It is useful to define the factors associated with childhood obesity in different populations, because this may lead to a better understanding of the aetiology of obesity and help to establish a preventive programme for obesity. Our findings would add to the body of knowledge about obesity from this part of the world since obesity is related to familial, environmental and individual factors.

The prevalence of obesity in a given population depends on the reference data, the cutoff level and the indicator used. In the present study, we used BMI as an indicator for obesity, with a cut-off level $>90$ th percentile of the age/sex-specific value of the reference NCHS population as this represents a nutritional concern. The NCHS reference data is now historical but the International Obesity Task Force will shortly publish a new reference data. The prevalence of obesity found in the present study was comparable to that found in children studied in other geographical areas [2], whilst it was higher than that reported in other populations [3-5]. Genetic and environmental differences may partially explain these differences in addition to methodological variations with regard to the definition of obesity.

Our data showed that female children tend to be fatter than males as expressed by the significantly higher BMI mean values in females than in males. This finding is inconsistent with Rona and Chinn [13], who showed that the 9- to 18-year-old boys were on the average more often obese than girls. As shown by numerous studies on adults, the amount of abdominal fat is more likely to affect morbidity and mortality. Since this is true also for children [14], it may be assumed that at least part of the metabolic consequences of obesity could affect obese children early in life, and this further emphasizes the necessity for identifying obesity during childhood and initiating early treatment. The pubertal status of the junior children (10-13 years) has influenced their fat deposition and body weight as evi- 
denced by the high rate of obesity among them, compared to the primary group (6-9 years).

The relation between SES and child obesity is unclear in the literature [15]. Differences in populations, methodologies, sampling variation, and the range of SES in the population may contribute to the differences observed. The present study used parental education and occupation as measures of SES. These variables were not found associated with childhood obesity. This finding was consistent with other studies $[16,17]$. Some researchers $[2,18]$ found a negative relation between social class and childhood obesity, while others $[19,20]$ reported a direct relation. The relation between parental SES and obesity in offspring may reflect the indirect effect of social class on parental fatness rather than the direct effect of social class in childhood obesity [21]. In Kuwait, SES groups are not clearly defined since the social class does not depend only on education and occupation.

The inverse relationship between the number of children in the family and child obesity is in concert with other studies [1,13], but the mechanism remains unclear. Children that come from families with more number of siblings may become more physically active. Besides, overprotection and overfeeding may contribute to higher rate of obesity in children of smaller families. Contrary to Rona and Chinn [13], maternal employment was found related to child obesity. Our data did not show a significant relationship between obesity and physical activity, while an inverse relationship was observed by Moussa et al. [22]. However, these results obtained from qualitative information drawn from interviews need to be interpreted with caution. Elevated blood pressure may be a consequence of obesity, and this was apparent from the significantly higher systolic and diastolic blood pressures seen in obese than in nonobese children.

The logistic regression analysis showed that family history of obesity, hypertension, and diabetes mellitus in parents, child's birth order, and respiratory diseases in the child were significant associated factors with obesity after adjusting for the confounding covariates, age and sex. However, Antonella et al. [23] showed no correlation between obesity and family history of hypertension or diabetes. Parental obesity was reported to be a risk factor for obesity among children [21], as parental influence appears to determine children's food intake, and the level of physical activity.

In conclusion, this study provided an overview of the prevalence of childhood obesity in a small rapidly developing population. Discrepancies and consistencies between our findings and others, with respect to obesity, support the hypothesis that obesity is related to family, environment, and individual characteristics. Factors associated with obesity need to be detected and corrected at a young age, to prevent consequences of obesity in adulthood [24].

\section{Acknowledgement}

This research was supported by the Kuwait University grant No. MC 039. 


\section{References}

1 Klish WJ: Childhood obesity: Pathophysiology and treatment. Acta Paediatr Jpn 1995;37:1-6.

2 Wolfe WS, Campbell CC, Frongillo EA, Haas JD, Melnik TA: Overweight schoolchildren in New York State: Prevalence and characteristics. Am J Public Health 1994;84 807-813.

3 Maffeis C, Schutz Y, Piccoli R, Gonfiantini E, Pinelli L: Prevalence of obesity in children in north-east Italy. Int J Obes 1993; 17:287-294.

4 Ball MJ, Wilson BD, Robertson IK, Wilson N, Russel DG: Obesity and body fat distribution in New Zealanders: A pattern of coronary heart disease risk. NZ Med J 1993;106: 69-72.

5 Al-Nuaim AR, Bamgboye EA, AlHerbish A: The pattern of growth and obesity in Saudi Arabian male school children. Int J Obes 1996;20: 1000-1005.

6 Bayoumi A, Moussa MAA: Kuwait nutritional survey, comparison of the nutritional status of Kuwaiti children 6-9 years with the NCHS/ CDC reference population. Int $\mathrm{J}$ Epidemiol 1985; 14:415-419.

7 Eid N, Al-Hooti S, Bourisly N, Khalafawi M: Nutritional anthropometry of school children in Kuwait. Nutr Rep Int 1986;33:253-260.

8 Cochran WG: Sampling Techniques. New York Wiley \& Sons, 1992.

9 Garrow JS, Webster Y: Quetelet's index $(\mathrm{W} / \mathrm{H} 2)$ as a measure of fatness. Int J Obes 1985;9:147-153.
10 Hamill PVV, Drizd TA, Johnson CL, Reed RB, Roche AF, Moore WM: Physical growth: National Center for Health Statistics percentiles. Am J Clin Nutr 1979;32:607629.

11 SPSS, Statistical Package for Social Sciences for Windows, User's Guide, release 7.5. New York, McGraw Hill, 1995.

12 EPI Info: Public Domain Software for Epidemiology and Disease Surveillance, version 6. Atlanta, Centers for Disease Control, Epidemiology Program Office, 1995.

13 Rona RJ, Chinn S: National Study of Health and Growth: Social and biological factors associated with weight-for-height and triceps skinfold of children from ethnic groups in England. Ann Hum Biol 1987; 14 231-248.

14 Burns TL, Moll PP, Lauer RM: The relation between ponderosity and coronary risk factors in children and their relatives: The Muscatine ponderosity family study. Am J Epidemiol 1989;129:973-987.

15 Sobal J, Stunkard AJ: Socioeconomic status and obesity: A review of the literature. Psychol Bull 1989;105: 260-275.

16 Power C, Maynihan CM: Social class and changes in weight-forheight between childhood and early adulthood. Int J Obes 1988;12:445453.

17 Lissau I, Sorensen TIA: Prospective study of influence of social factors in childhood on risk of overweight in young adulthood. Int J Obes 1992; 16:169-175.
18 Rolland-Cachera MF, Bellisle F: No correlation between adiposity and food intake: Why are working class children fatter? Am J Clin Nutr 1986;44:779-787.

19 Garn SM, Hopkins PJ, Ryan AS: Differential fatness gain of low income boys and girls. Am J Clin Nutr 1981;34:1465-1468.

20 Gortmaker SL, Dietz WH, Cheung LWY: Inactivity, diet, and the fattening of America. J Am Diet Assoc 1990;90:1247-1255.

21 Maffeis C, Micciolo R, Must A, Zaffanello M, Pinelli L: Parental and perinatal factors associated with childhood obesity in north-east Italy. Int J Obes 1994;18:301-305.

22 Moussa MAA, Skaik MB, Selwanes SB, Yaghy OY, Bin-Othman SA: Factors associated with obesity in school children. Int J Obes 1994;18: 513-515.

23 Antonella EP, Luca S, Emilia DF, Rosaria PM, Annarita C, Giuseppe C, Franco C, Guiliana V, Adriana F, Salvatore DM, Armido R: Familial and environmental influences on body compositions and body fat distribution in childhood in Southern Italy. Int J Obes 1994; 18:596-601.

24 Sorensen TIA, Sonne-Holm S: Risk in childhood of development of severe adult obesity: Retrospective, population-based case-cohort study. Am J Epidemiol 1988;127:104113. 